\title{
Arbuscular Mycorrhizal symbiosis in four Al-tolerant wheat genotypes grown in an acidic Andisol
}

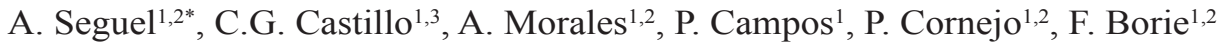 \\ ${ }^{I}$ Scientific and Technological Bioresource Nucleus -BIOREN-UFRO- Universidad de La Frontera, Temuco, \\ Chile. ${ }^{2}$ Departamento de Ciencias Químicas y Recursos Naturales, Universidad de La Frontera, Temuco, \\ Chile. ${ }^{3}$ Escuela de Agronomía, Facultad de Recursos Naturales, Universidad Católica de Temuco, Temuco, \\ Chile. ${ }^{*}$ Corresponding author: alex.seguel@ufrontera.cl
}

\begin{abstract}
Arbuscular mycorrhizal (AM) fungi play an important role in protecting host plant against phytotoxic aluminum (Al) in soil. The aim of this work was to analyze the effect of AM fungi native from acid soil on the growth of four Al-tolerant wheat (Triticum aestivum L.) genotypes. A greenhouse experiment was conducted using three near isogenic Chilean wheat genotypes ('Crac', 'Invento' and 'Otto') and one of recognized Al-tolerance ('Atlas 66') which were grown in an acid Andisol with 34\% Al-saturation. The plant dry biomass and root colonization were determined at six early growth stages and AM spore density, glomalin (as GRSP) and acid phosphatase (P-ase) activity were analyzed at two stages; i) 11 days after sowing -DAS-, and at 60 DAS. Results showed that in all genotypes AM root colonization was not inhibited in spite of high soil Al saturation in the soil and a significant root colonization degree was observed at the first phenological stage mainly in the native wheat genotypes. Also, 'Crac' and 'Invento' genotypes showed the highest densities of AM spores and GRSP production. All wheat cultivars increased the P-ase activity overtime. Root biomass correlated positive and significantly with root colonization $(\mathrm{r}=0.71 ; \mathrm{P}<0.001)$ and inversely with $\mathrm{AM}$ spores $(\mathrm{r}=-0.61 ; \mathrm{P}<0.001)$. 'Atlas 66' showed a high adaptability to grow in acid conditions but produced the lesser amounts of AM propagules, which suggest that this genotype would show Al-tolerance mechanisms not fully associated to AM symbiosis as the Chilean wheat cultivars do. In conclusion, the higher early root colonization, AM spores and GRSP production associated to native wheat genotypes could indicate that AM symbiosis play a principal role in the $\mathrm{Al}$ tolerance capacity of T. aestivum developed in those soils with high Al levels and fungal native populations adapted to this conditions.
\end{abstract}

Keywords: Wheat, arbuscular mycorrhizal fungi, Al-tolerance, acidic soil 


\section{Introduction}

Plant growth in acidic soils is limited by low levels of available phosphorus $(\mathrm{P})$ and the high presence of phytotoxic aluminum $\left(\mathrm{Al}^{3+}\right)$, which causes deleterious effects on plant physiology and growth (Fageria and Baligar, 2008). There are several mechanisms to alter the chemical form and toxicity of $\mathrm{Al}$ in the environment and/or function within plant cells to reduce the negative effects of $\mathrm{Al}$ on plant metabolism (Kochian et al., 2004). In this sense, sufficient genetic variation in Al-tolerance has been reported among wheat cultivars (Raman et al., 2005; Liu et al., 2015). In relation to the alleviation of these abiotic stresses is where the AM association plays an important role in acid soils, through the interaction Al-P in colonized roots (Marschner, 1995), an improvement of nutrient absorption (Borie and Rubio, 1999; Lux and Cumming, 2001; Cornejo et al., 2008; Barea, 2015) or through kidnapping the $\mathrm{Al}$ by an enhancement of root organic acid excretion (Klugh-Stewart and Cumming, 2009) and glomalin related soil protein (GRSP) production by AM fungal structures (Aguilera et al., 2011, Seguel et al., 2013; 2015). In the case of acidic soils and/or soils with elevated Al levels, there is a variation in the response of AM fungi ecotypes potentially $\mathrm{Al}$ tolerant in association with the different host plants which is related to differences in sensitivity of life stage events, such as spore germination, germ tube growth, hyphal growth, root colonization and persistence (Klugh and Cumming, 2007). These variations can do the difference in the $\mathrm{Al}$ tolerance of different wheat genotypes grown under these conditions. Across many studies of AM development in plants exposed to $\mathrm{Al}$, there is a tendency for fungal colonization to be unaffected or increase of host roots, although some fungal species/isolates do exhibit reductions in colonization in response to $\mathrm{Al}$ in the environment (Seguel et al., 2015). Therefore, there is not a consensus of the degree of $\mathrm{Al}$ tolerance in host plants in relation to levels of root colonization in the long term. However, an early AM colonization positively affects the development of the plant grown under these conditions by improving the acquisition of water and nutrients in the first growth stages of the plant and will lead to a better response against this abiotic stress (Seguel et al., 2012). In other hand, GRSP produced by $\mathrm{AM}$ fungi will sequester $\mathrm{Al}^{3+}$ over long time frames and this, together with $\mathrm{Al}$ accumulation in fungal structures as spores and hyphae, could provide an important $\mathrm{Al}$ tolerance mechanism (Aguilera et al., 2011; Seguel et al., 2013; 2015). Considering that the different behavior of wheat cultivars grown in acidic soils could be related to response factors of AM symbiosis we hypothesized that the Al tolerance of Chilean wheat cultivars could be in part related to an early root colonization and the greatest response of these genotypes to form associations with native populations adapted to acidic conditions. For this reason, the aim of this work was to study the root colonization at six different growth stages and the AM fungal propagules density, P-ase activity and GRSP accumulation in three Chilean Al-tolerant wheat cultivars using 'Atlas 66' for comparison as a wellknown Al-tolerant wheat cultivar.

\section{Materials and Methods}

The soil used was an Andisol (Gorbea series, medial, mesic, Typic Dystrandept) collected to $20 \mathrm{~cm}$ depth. The soil was air-dried, sieved through a $5 \mathrm{~mm}$ mesh, and $250 \mathrm{~mL}$ were filled into $300 \mathrm{~mL}$ plastic pots. Some characteristics of used soil are described in Table 1. Seeds of three near-isogenic Chilean Al-tolerant wheat genotypes of Triticum aestivum L. (wheat), 
'Crac', 'Invento' and 'Otto' were surface-sterilized with $2 \%$ Cloramin-T solution for $3 \mathrm{~min}$ and rinsed thoroughly. Additionally, the gold-standard Al-tolerant wheat genotype 'Atlas 66' (Carver et al., 1993) was included as a comparison treatment. Two plants per pot were grown under greenhouse conditions, with temperatures ranging from $25 \pm 3^{\circ} \mathrm{C}$ day $/ 15 \pm 3^{\circ} \mathrm{C}$ night, a $16 / 8 \mathrm{~h}$ light/dark photoperiod and a relative humidity of $80-90 \%$. A photosynthetic photon flux density of $400-500 \mathrm{mmol} \mathrm{m}^{-2} \mathrm{~s}^{-1}$ was applied as supplementary light when necessary.

Table 1. Selected chemical properties of the used soil (Gorbea Serie)

\begin{tabular}{|c|c|}
\hline & Soil used \\
\hline Available $\mathrm{P}\left(\mathrm{mg} \mathrm{kg}^{-1}\right)^{\mathrm{A}}$ & 21 \\
\hline Total $\mathrm{P}\left(\mathrm{mg} \mathrm{kg}^{-1}\right)^{\mathrm{B}}$ & 3912 \\
\hline Organic $\mathrm{P}\left(\mathrm{mg} \mathrm{kg}^{-1}\right)^{\mathrm{C}}$ & 1848 \\
\hline $\mathrm{pH}^{\mathrm{D}}$ & 4.8 \\
\hline Organic matter $(\%)^{\mathrm{E}}$ & 11 \\
\hline \multicolumn{2}{|c|}{ Exchangeable cations $\left(\mathrm{cmol}_{(+)} \mathrm{kg}^{-1}\right)$} \\
\hline $\mathrm{Na}^{\mathrm{F}}$ & 0.04 \\
\hline $\mathrm{Ca}^{\mathrm{F}}$ & 0.91 \\
\hline $\mathrm{Mg}^{\mathrm{F}}$ & 0.34 \\
\hline $\mathrm{Al}^{\mathrm{G}}$ & 0.74 \\
\hline ECEC $^{\mathrm{H}}$ & 2.34 \\
\hline Al saturation $(\%)$ & 31.62 \\
\hline Base saturation $\left(\mathrm{cmol}_{(+)} \mathrm{kg}^{-1}\right)$ & 1.60 \\
\hline
\end{tabular}

All of the analytical techniques were carried out according to the Normalisation and Accreditation Commission of the Chilean Soil Science Society (Zagal and Sadzawka, 2007).

${ }^{\text {A }}$ Extractable by Olsen method.

${ }^{\text {B }}$ Determined by soil oxidation with sodium hypobromite

${ }^{\mathrm{C}}$ Determined by Hedley fractionation procedure.

${ }^{\text {D }}$ Measured in $\mathrm{H}_{2} \mathrm{O}$.

E Walkley and Black method.

${ }^{\mathrm{F}}$ Extracted by $1 \mathrm{M}$ ammonium acetate.

${ }^{\mathrm{G}}$ Extracted by $1 \mathrm{M}$ potassium chloride.

${ }^{\mathrm{H}}$ Effective cation exchange capacity.
The plants were irrigated manually with distilled water as needed. Nitrogen $(\mathrm{N})$ was supplied in two fractions, at establishment $(30 \%$ total $\mathrm{N})$ and at 6 weeks of cultivation $(70 \%$ total $\mathrm{N})$, for a total of $0.112 \mathrm{~g} \mathrm{~N} \mathrm{~kg}^{-1}$ soil, which represents a common fertilization rate. Moreover, the soil was amended with $0.016 \mathrm{~g} \mathrm{P} \mathrm{kg}$ soil- ${ }^{-1}$ as $\mathrm{NaH}_{2} \mathrm{PO}_{4}$ and $0.063 \mathrm{~g} \mathrm{~K} \mathrm{~kg} \mathrm{soil}^{-1}$ as $\mathrm{KCl}$ via a solution prior to establishment. For plant growth (root and shoot biomass) and root colonization six harvest stages were established at 11, 15, 21, 28, 45 and 60 days after sowing (DAS). On other hand, AM spores density, GRSP and P-ase activity were determined at 11 and 60 DAS. The experimental design was fully factorial, with four (4) wheat cultivars, six (6) harvest stages and four (4) replicates in each combination.

At each stage of harvest, the plants were separated into roots and shoots and dried at $65^{\circ} \mathrm{C}$ in a forced-air oven for $48 \mathrm{~h}$, and the dry root and shoot was weighed. Before drying, a portion of the root was separated and AM colonization was measured. Root samples were gently washed under tap water, stained with trypan blue after boiling in $10 \% \mathrm{KOH}$ and mycorrhizal colonization was determined using the gridline intersect method (Giovannetti and Mosse, 1980). AM spores were collected from soils by wet sieving and decanting according to the methodology described by Sieverding (1991). The total GRSP was determined using the extraction method described by Wright and Upadhyaya (1998), with minor modifications. Protein content of the crude extract was determined using the Bradford assay (Bio Rad Protein Assay; Bio Rad Laboratories), with bovine serum albumin as the standard. Finally, acid phosphatase (P-ase) activity was determined by the p-nitrophenyl phosphate method according to Tabatabai and Bremner (1969) modified by Rubio et al. (1990) for Andisols. Data were analyzed using a factorial analysis of variance (ANOVA) followed by Tukey-Kramer's LSD to identify significant differences between treatment means. 
In all cases, significance was established at $\mathrm{P}<$ 0.05 . All statistical analyses were carried out using SPSS software v. 15.0 (SPSS, Inc., Chicago, IL).

\section{Results and Discussion}

The maintenance of plant growth under exposure to $\mathrm{Al}$ may be the best indicator of $\mathrm{Al}$ tolerance in acid soils (Kochian et al., 2004). In this study, root and shoot biomass were increased over time in the 4 genotypes (Table 2). In this sense, at 11 DAS, 'Otto' had the highest plant biomass, showing significant differences with the other wheat cultivars in that harvest time (Table 2). However, at 60 DAS the most important plant biomass increment was observed in 'Atlas 66' genotype (Table 2) reaching 81.7 and 174.9 mg plant $^{-1}$ in root and shoot, respectively, showing its high adaptability to soils with great Al levels as Gorbea soil series.

Table 2. Root and shoot biomass production and arbuscular mycorrhiza root colonization in four wheat cultivars grown in an acidic soil with high Al levels at six plant growth stages (days after sowing -DAS-).

\begin{tabular}{|c|c|c|c|c|}
\hline Genotypes & $\begin{array}{l}\text { Growth Stages } \\
\text { (DAS) }\end{array}$ & $\begin{array}{l}\text { Root dry weight } \\
\left(\text { mg plant }^{-1}\right)\end{array}$ & $\begin{array}{l}\text { Shoot dry weight } \\
\left(\mathrm{mg} \mathrm{plant}^{-1}\right)\end{array}$ & $\begin{array}{l}\text { Root colonization } \\
(\%)\end{array}$ \\
\hline \multirow[t]{6}{*}{ Atlas 66} & 11 & $12.2 \pm 0.7^{\mathbf{h}}$ & $16.2 \pm 0.6^{\mathrm{fg}}$ & $3.8 \pm 0.4^{\mathrm{g}}$ \\
\hline & 15 & $14.6 \pm 0.3^{\mathrm{gh}}$ & $24.2 \pm 0.2^{\mathrm{efg}}$ & $5.0 \pm 0.3^{\mathrm{g}}$ \\
\hline & 21 & $25.2 \pm 0.7^{\mathrm{def}}$ & $40.3 \pm 0.2^{\mathrm{def}}$ & $28.3 \pm 3.5^{\text {cd }}$ \\
\hline & 28 & $25.7 \pm 1.2^{\text {de }}$ & $44.8 \pm 1.9^{\text {de }}$ & $29.8 \pm 2.0^{\mathrm{cd}}$ \\
\hline & 45 & $32.1 \pm 1.5^{\mathrm{cd}}$ & $70.9 \pm 10.5^{\mathrm{cd}}$ & $34.5 \pm 0.2^{\mathrm{abc}}$ \\
\hline & 60 & $81.7 \pm 2.7^{\mathbf{a}}$ & $174.9 \pm 16.5^{\mathrm{a}}$ & $30.4 \pm 2.4^{\text {bc }}$ \\
\hline \multirow[t]{6}{*}{ Crac } & 11 & $13.3 \pm 0.7^{\mathbf{h}}$ & $11.3 \pm 0.1^{\mathrm{g}}$ & $7.8 \pm 0.8^{\mathrm{fg}}$ \\
\hline & 15 & $18.3 \pm 0.8^{\mathrm{fgh}}$ & $14.2 \pm 1.2^{\mathrm{fg}}$ & $11.3 \pm 0.7^{\mathrm{fg}}$ \\
\hline & 21 & $20.4 \pm 0.4^{\mathrm{efg}}$ & $20.5 \pm 1.2^{\mathrm{efg}}$ & $14.3 \pm 1.0^{\mathrm{ef}}$ \\
\hline & 28 & $21.8 \pm 1.0^{\mathrm{efg}}$ & $26.2 \pm 1.5^{\mathrm{efg}}$ & $31.1 \pm 1.0^{\text {abe }}$ \\
\hline & 45 & $22.5 \pm 0.9^{\mathbf{e f g}}$ & $32.1 \pm 4.1^{\mathrm{defg}}$ & $38.7 \pm 2.3^{\mathrm{a}}$ \\
\hline & 60 & $28.1 \pm 1.7^{\mathrm{de}}$ & $41.5 \pm 3.8^{\text {def }}$ & $26.8 \pm 1.7^{\mathrm{cd}}$ \\
\hline \multirow[t]{6}{*}{ Invento } & 11 & $13.1 \pm 0.6^{\mathbf{h}}$ & $10.5 \pm 0.9^{g}$ & $9.3 \pm 0.8^{\mathbf{f g}}$ \\
\hline & 15 & $16.8 \pm 0.2^{\mathrm{fgh}}$ & $21.6 \pm 0.3^{\mathrm{efg}}$ & $11.6 \pm 1.1^{\mathrm{fg}}$ \\
\hline & 21 & $19.4 \pm 0.4^{\mathrm{fgh}}$ & $25.5 \pm 1.6^{\mathrm{efg}}$ & $11.7 \pm 1.6^{\mathrm{fg}}$ \\
\hline & 28 & $22.5 \pm 0.9^{\mathrm{efg}}$ & $57.0 \pm 1.7^{\mathrm{cd}}$ & $26.9 \pm 1.2^{\text {cd }}$ \\
\hline & 45 & $25.1 \pm 1.4^{\text {edf }}$ & $93.2 \pm 3.4^{\mathrm{bc}}$ & $27.9 \pm 0.8^{\text {cd }}$ \\
\hline & 60 & $36.1 \pm 1.0^{\mathrm{c}}$ & $104.8 \pm 6.3^{\mathbf{b}}$ & $33.9 \pm 1.9^{\text {abc }}$ \\
\hline \multirow[t]{6}{*}{ Otto } & 11 & $16.4 \pm 0.7^{\mathrm{gh}}$ & $18.3 \pm 0.5^{\mathrm{efg}}$ & $7.7 \pm 0.9^{\mathrm{fg}}$ \\
\hline & 15 & $22.7 \pm 0.3^{\text {ef }}$ & $21.8 \pm 2.0^{\mathrm{efg}}$ & $11.4 \pm 0.5^{\mathrm{fg}}$ \\
\hline & 21 & $30.1 \pm 0.6^{\mathrm{cd}}$ & $35.4 \pm 1.2^{\text {defg }}$ & $38.1 \pm 2.1^{\mathbf{a b}}$ \\
\hline & 28 & $36.4 \pm 1.0^{\mathbf{c}}$ & $50.4 \pm 1.4^{\text {cde }}$ & $37.9 \pm 1.1^{\mathbf{a b}}$ \\
\hline & 45 & $45.1 \pm 1.4^{\mathbf{b}}$ & $75.7 \pm 5.7^{\mathfrak{c}}$ & $28.9 \pm 0.6^{\text {cd }}$ \\
\hline & 60 & $52.7 \pm 2.1^{\mathbf{b}}$ & $126.2 \pm 8.7^{\mathbf{b}}$ & $22.1 \pm 1.1^{\mathrm{de}}$ \\
\hline \multicolumn{5}{|l|}{ ANOVA } \\
\hline Cultivar & & $207.4 * * *$ & $63.1 * * *$ & $8.1 * * *$ \\
\hline Growth stages & & $490.9^{* * *}$ & $207.4 * * *$ & $225.4 * * *$ \\
\hline Interaction & & $74.1 * * *$ & $18.4 * * *$ & $20.8 * * *$ \\
\hline
\end{tabular}

Means \pm standard errors $(\mathrm{n}=4)$ followed by different letter in a column are significantly different from each other by to orthogonal contrasts test $(\mathrm{P}<0.05)$. Significance conventions: * $\mathrm{P}<0.05$; ** $\mathrm{P}<0.01$; *** $\mathrm{P}<0.001$. 
'Atlas 66' is an Al-tolerant cultivar released in the early 1940's from North Carolina, USA and it has been extensively studied for its great Al-tolerance (GUO Pei-guo et al., 2007). The form of constitutive phosphate release and $\mathrm{Al}$-inducible malate release from the root apices are its principal Al-tolerance mechanism (Pellet et al., 1996; Papernik et al., 2001). It has been reported that more than one gene might contribute to Al tolerance in 'Atlas 66' (Tang et al., 2002; Ma et $a l ., 2005)$. In this sense, the analysis of gene expression profile of Near-Isogenic lines to 'Atlas 66' under $\mathrm{Al}$ stress identified 25 functional genes in response to Al stress (Xiao et al., 2005). While for Chilean wheat cultivars there are not studies related to genes involved in their Al-tolerance, Raman et al. (2005) suggested that ALMTl is the gene fully responsible for A1 tolerance in wheat. However, some other findings were not fully in agreement with this assumption and suggested that multi-gene mechanisms might be involved in wheat A1 tolerance (Pellet et al., 1996; Xiao et al., 2005; Ma et al., 2006). Despite the above, some general $\mathrm{Al}$ tolerance mechanisms have been proposed for Chilean wheat cultivars, principally related to the role of AM fungi (Seguel et al., 2012; 2013). In this sense, the root colonization plays an important role in the Al-tolerance of wheat cultivars grown in acidic soils. At 11 and 15 DAS, 'Crac', 'Invento' and 'Otto' had higher root colonization than 'Atlas 66' and the Chilean wheat genotypes were significantly different to foreign wheat (Table 2). The fast AM colonization in some cultivars is probably due to the presence of more infective fungal structures and the difference in the architecture of the external mycelium (Hart and Reader, 2005; Castillo et al., 2012). Different AM colonization levels in different genotypes can also be due to an increased $\mathrm{Al}$ tolerance across time by some cultivars that have a better adaptation to these conditions, or by the effect of different AM fungal species colonizing the plants. On the other hand, at 45 and 60
DAS the root colonization was similar between the four genotypes showing that AM fungal colonization is not inhibited by high $\mathrm{Al}$ saturation and that an early colonization could be key in this process (Seguel et al., 2012).

In addition to early AM root colonization as an Altolerance response in some plants; spore germination, GRSP production and P-ase activity are affected when a plant is exposed to Al stress. Such differences can be a consequence of substantial genetic variation among and within AM fungi taxa (Avio et al., 2009). In this study, the higher spore density was observed in 'Invento', which reached 271 and 260 spores $100 \mathrm{~g} \mathrm{soil}^{-1}$ at 11 and 66 DAS, respectively. Moreover, 'Crac' and 'Invento' spore numbers were significantly different from those of 'Atlas 66' and 'Otto' (Figure 1A). Similar results were found by Seguel et al. (2012) with the Chilean wheat cultivars where 'Crac' and 'Invento' showed a high sporulation by AM fungi colonizing wheat occurred in acidic soil. On other hand, greatest quantities of GRSP were observed in 'Invento' at 11 DAS, reaching $36.9 \mathrm{mg} \mathrm{g}^{-1}$ soil (Figure 1B). However, GRSP production was increased overtime in 'Atlas 66' and 'Otto' wheat cultivars. At 60 DAS, 'Atlas 66' showed the highest GRSP levels with $32.8 \mathrm{mg} \mathrm{g}^{-1}$ soil but the Chilean wheat cultivars can accumulate more than $6 \%$ of $\mathrm{Al}$ bound to GRSP (unpublished data). This suggests that AM fungi confer a certain degree of Al tolerance to wheat related to the Al-binding capacity of GRSP, as has been reported (Aguilera et al., 2011; Seguel et al., 2013; 2015).

In addition to direct effects of AM fungi in conferring $\mathrm{Al}$ tolerance by increased number of AM propagules or an improved nutritional status of host plant, the AM fungi play important roles through Al-P interactions (Marschner, 1995; Seguel et al., 2015). In this sense, the exudation of organic acids (as malate/ citrate) or enzymes (as acid phosphatases) into the rhizosphere are key factors (Ciereszko et al., 2011). 

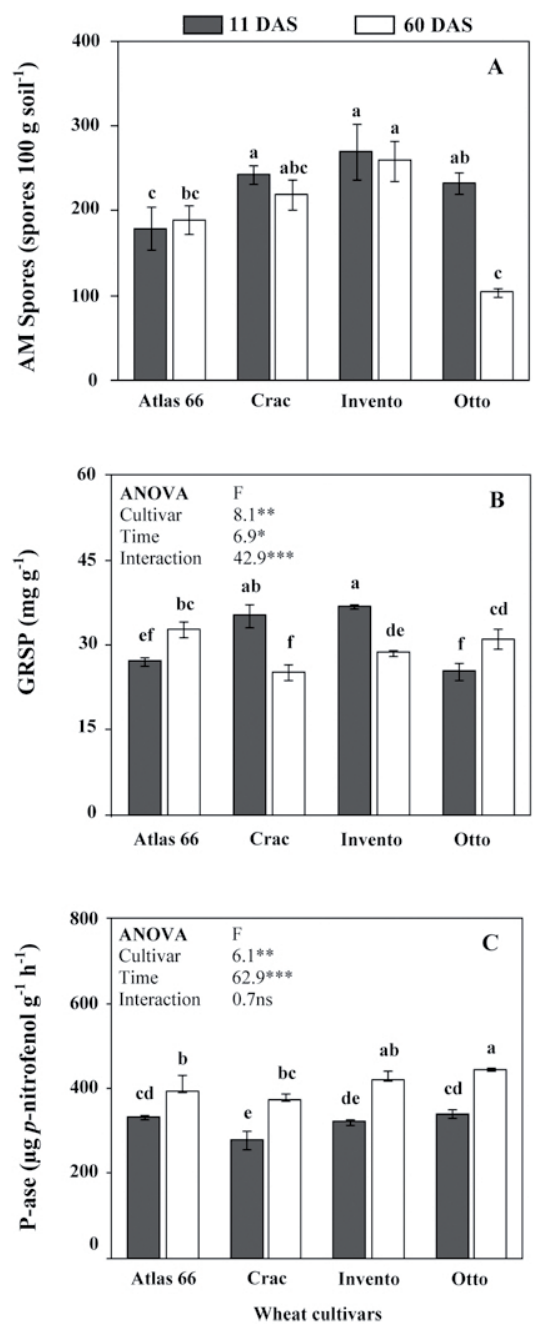

Figure 1. Spore number (A), glomalin-related soil protein -GRSP- (B), and P-ase activity (C) for four wheat cultivars grown in an acidic soil at 11 and 60 days after sowing -DAS-. Bars with different letters are significantly different by Tukey's HSD (Means \pm standard errors, $\mathrm{n}=4$, ANOVA significance: * $\mathrm{P} \leq 0.05 ; * * \mathrm{P} \leq 0.01 ; * * * \mathrm{P} \leq 0.001)$.
In our study, all wheat cultivars increased the P-ase activity overtime (Figure 1C) as response to high Al-levels in soil. At 60 DAS, 'Otto' and 'Invento' showed the highest $\mathrm{P}$-ase activity reaching 444 and $420 \mu \mathrm{g} p$-nitrofenol $\mathrm{g}^{-1} \mathrm{~h}^{-1}$ respectively. If we considered 'Atlas 66' as reference of Al-tolerant wheat cultivar and the importance of the release of acid phosphatases as an indirect mechanism of Al-tolerance in the rhizosphere by $\mathrm{P}$ desorption (Ciereszko et al., 2011) or by hydrolysis of the high organic $\mathrm{P}$ that these soils contain (Borie and Rubio, 2003) we can highlight the high Al tolerance of the Chilean wheat cultivars here studied (Figure 1C). It was observed that all cultivars essayed presented some root colonization degree at the first growth stage, suggesting a positive relationship between root mycorrhizal colonization and Al activity in the soil (Seguel et al., 2012) principally with some specific native ecotypes of AM fungi (Aguilera et al., 2014). In this sense, a significant relationship was obtained between AM colonization and root dry biomass ( $\mathrm{r}=$ $0.71 ; \mathrm{P}<0.001$ ) (Figure 2A). Other aspect to take into account is that one of the results of AM fungal adaptation to environmental stress conditions (as high $\mathrm{Al}$ or other metals levels) is the enhanced production of propagules, which could ensure root colonization in other plants or in further annual crops (Cornejo et al., 2007; Meier et al., 2015). In this sense, a significant and negative relationship was observed between root biomass and AM spores density $(\mathrm{r}=-0.61 ; \mathrm{P}<0.001)$ showing that when the plant is more affected (less root biomass) the spores number is increased (Figure 2B). While Del Val et al. (1999) have shown that spores abundance is decreased by some stress factors as heavy metals, Borie and Rubio (1999) and Seguel et al. $(2012 ; 2015)$ have demonstrated the ability of 

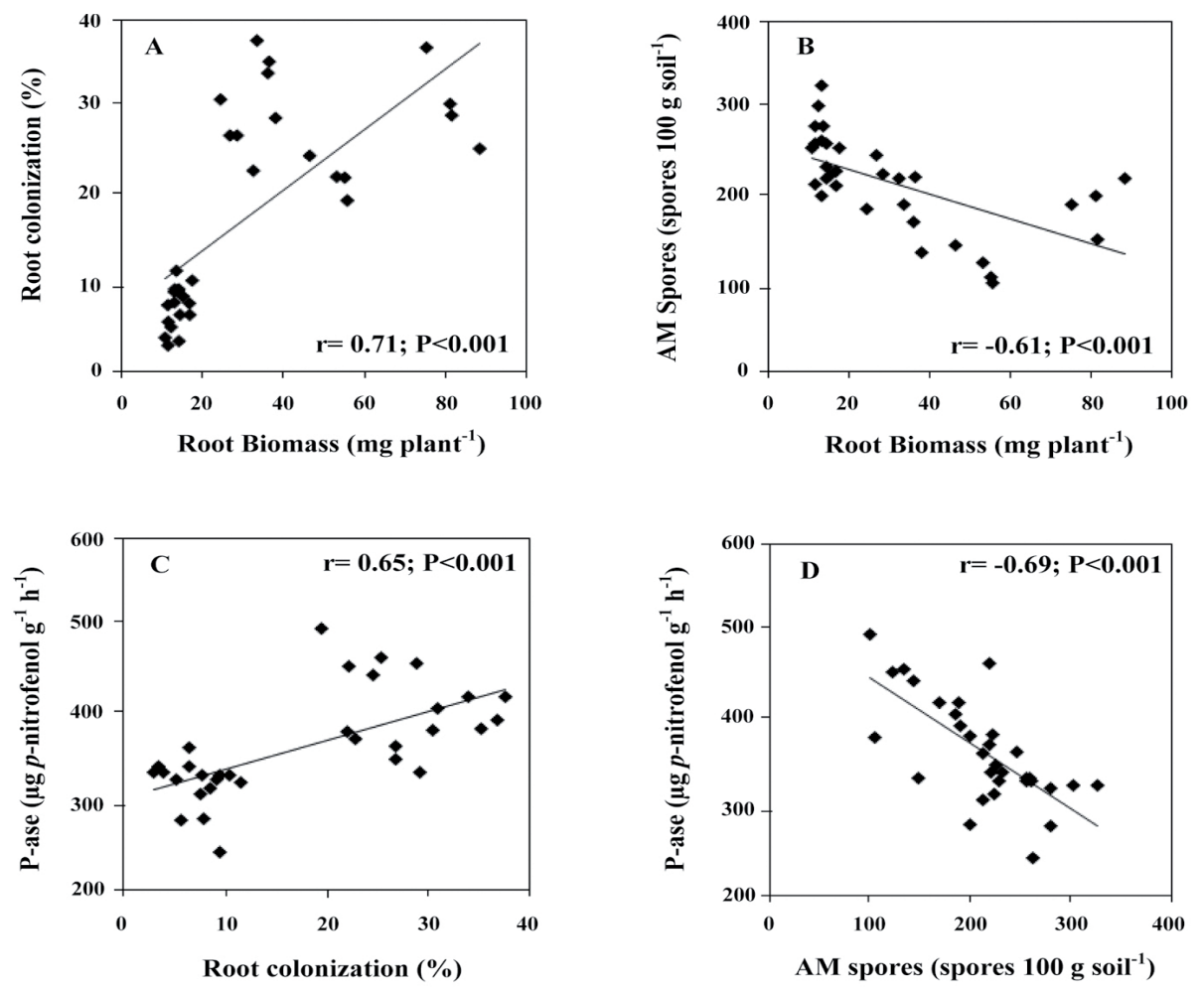

Figure 2. Relationships between: (A) Root dry weight and root colonization; (B) Root dry weight and AM spores; (C) Root colonization and P-ase activity; (D) AM spores and P-ase activity of four wheat cultivars grown in an acidic soil at 11 and 60 days after sowing

the AM fungi to increase the sporulation when the host plant grows under high $\mathrm{Al}$ levels in soil. On the other hand, the phosphatase activity was significantly correlated with root colonization $(\mathrm{r}=0.65 ; \mathrm{P}<0.001)$ and negatively correlated with the AM spore density $(\mathrm{r}=-0.69 ; \mathrm{P}<0.001)$ (Figure $2 \mathrm{C}$ and $2 \mathrm{D})$, reinforcing the idea that acid phosphatase release is directly influenced by AM fungi and increased in host plants grown under environmental stresses. Finally, we could observed that root dry weight $(\mathrm{P}<0.001)$, shoot dry weight $(\mathrm{P}<0.001)$ and root colonization $(\mathrm{P}<0.001)$ were influenced by wheat genotype/growth stages interaction (Table 2) and AM spores $(\mathrm{P}<0.001)$, GRSP $(\mathrm{P}<0.01)$ and $\mathrm{P}$-ase activity $(\mathrm{P}<0.01)$ were affected by wheat cultivar. In this sense, the plant response of different wheat genotypes grown in acidic soils with high Al levels can be modulated by the presence of symbiotic AM fungi (Seguel et al., 2013; Aguilera et al., 2014) and such changes in plant-soil interactions vary according with AM fungi species and isolates. 


\section{Conclusions}

High Al saturation in soil did not affect the growth of the four wheat cultivars grown in acidic soils. This performance was associated with an important degree of root colonization in the first phenological stages. In addition, the higher amounts of AM fungal propagules were observed in Chilean wheat cultivars, principally 'Crac' and 'Invento' showing the compatibility of these cultivars with native populations of AM fungi adapted to acidic conditions. On the other hand, spore number negatively correlated with root biomass, supporting the capacity of these cultivars to increase the sporulation and ability for sequester $\mathrm{Al}$ in their structure when the host plant grows in presence of Al-toxicity. Finally, 'Atlas 66' showed its high adaptability to grow in acidic soils. However, the lesser root colonization observed at the first stages and lesser amounts of AM propagules suggest that this cultivar presents Al-tolerance mechanisms not fully associated to AM symbiosis as the Chilean wheat cultivars do.

\section{Acknowledgments}

We fully acknowledge the financial support of the FONDECYT 1130541 (Fernando Borie), FONDECYT 3140623 (Alex Seguel) and FONDECYT 1120890 (Pablo Cornejo) grants from the Comisión Nacional de Investigación Científica y Tecnológica (CONICYT), Chile.

\section{References}

Aguilera, P., Borie, F., Seguel, A., Cornejo, P. 2011. Fluorescence detection of aluminum in arbuscular mycorrhizal fungal structures and glomalin using confocal laser scanning microscopy. Soil Biol. Biochem. 43, 2427-2431.

Aguilera, P., Cornejo, P., Borie, F., Barea, J.M., von Baer, E., Oehl, F. 2014. Diversity of arbuscular mycorrhizal fungi associated with Triticum aestivum L. plants growing in an Andosol with high aluminum level. Agr. Ecosyst. Environ. 186, 178-184.

Avio, L., Cristani, C., Giovannetti, S.P. 2009. Genetic and phenotypic diversity of geographically different isolates of Glomus mosseae. Can. J. Microbiol. 55, 242-253.

Barea, J.M. 2015. Future challenges and perspectives for applying microbial biotechnology in sustainable agriculture based on a better understanding of plant-microbiome interactions. J. Soil Sci. Plant Nutr. 15(2) 261-282.

Borie, F., Rubio, R. 1999. Effects of arbuscular mycorrhizae and liming on growth and mineral acquisition of aluminium-tolerant and aluminium-sensitive barley cultivars. J. Plant Nutr. 22, 121-137.

Borie, F., Rubio, R. 2003. Total and organic phosphorus in Chilean volcanic soils. Gayana Botánica. 60, 69-78.

Castillo, C.G., Puccio, F., Morales, D., Borie, F., Sieverding, E., 2012. Early arbuscular mycorrhiza colonization of wheat, barley and oats in Andosols of southern Chile. J. Soil Sci. Plant Nutr. 12(3) 511-524.

Carver, B.F., Whitmore, W.E., Smith, E.L., Bona, L. 1993. Registration of four aluminum-tolerant winter wheat germplasms and two susceptible near-isolines. Crop Sci. 33, 1113-1114.

Ciereszko, I., Szczygła, A., Sebrowska, E. 2011. Phosphate deficiency affects acid phosphatase activity and growth of two wheat varieties. J. Plant Nutr. 34(6), 815-829.

Cornejo, P., Borie, F., Rubio, R., Azcón, R. 2007. Influence of nitrogen source on the viability, functionality and persistence of Glomus etunicatum fungal propagules in an Andisol. Applied Soil Ecology 35 (3), 423-431. 
Cornejo, P., Rubio, R., Castillo, C., Azcón, R., Borie, F. 2008. Mycorrhizal effectiveness on wheat nutrient acquisition in an acidic soil from southern Chile as affected by nitrogen sources. J. Plant Nutr. 31(9), 1555 -1569.

Del Val, C., Barea, J.M., Azcón-Aguilar, C. 1999. Diversity of arbuscular mycorrhizal fungus populations in heavy-metal-contaminated soils. Appl. Environ. Microbiol. 65, 718-723.

Fageria, N.K., Baligar, V.C. 2008. Ameliorating soil acidity of tropical Oxisols by liming for sustainable crop production. Adv. Agron. 99, 345-431.

Giovanetti, M., Mosse, B. 1980. An evaluation of techniques for measuring vesicular-arbuscular mycorrhizal infection in roots. New Phytol. 84, 489-500.

Guo, Pei-guo., Bai, Gui-hua., LI, Rong-hua., Carver, B., Baum, M. 2007. Molecular Characterization of Atlas 66-Derived Wheat Near-lsogenic Lines Contrasting in Aluminum (Al) Tolerance. Agr. Sci. China. 6(5), 522-528.

Hart, M.M., Reader, R.J. 2005. The role of the external mycelium in early colonization for three arbuscular mycorrhizal fungal species with different colonization strategies. Pedobiologia. 49, 269-279.

Klugh, K., Cumming, J., 2007. Variations in organic acid exudation and aluminum resistance among arbuscular mycorrhizal species colonizing Liriodendron tulipifera. Tree Physiol. 27, 1103-1112.

Klugh-Stewart, K., Cumming, J. 2009. Organic acid exudation by mycorrhizal Andropogon virginicus L. (broomsedge) roots in response to aluminum. Soil Biol. Biochem. 41, 367-373.

Kochian, L.V., Hoekenga, O.A., Pineros M.A. 2004. How do crop plants tolerate acid soils?.: mechanisms of aluminum tolerance and phosphorous efficiency. Annu. Rev. Plant Biol. 55, 459-493.

Liu, M., Yu, M., Li, G., Brett, F.C., Yan, L. 2015. Genetic characterization of aluminum tolerance in winter wheat. Mol Breeding 35:205. DOI 10.1007/ s11032-015-0398-y

Ma, H., Bai, G., Lu, W. 2006. Quantitative trait loci for Aluminum resistance in wheat cultivar Chinese Spring. Plant Soil. 283, 239-249.

Ma, H., Bai, G., Zhou, L., Carver, B. 2005. Molecular mapping of a quantitative trait locus for aluminum tolerance in wheat cultivar Atlas 66. Theor. Appl. Genet. 112, 51-57.

Marschner, H. 1995. Mineral Nutrition of Higher Plants, second ed. Academic Press, Inc., San Diego, CA.

Meier, S., Cornejo, P., Cartes, P., Borie, F., Medina, J., Azcón, R. 2015. Interactive effect between $\mathrm{Cu}$-adapted arbuscular mycorrhizal fungi and biotreated agrowaste residue to improve the nutritional status of Oenothera picensis growing in Cu-polluted soils. J. Plant Nutr. Soil Sci. 178, $126-135$.

Papernik, LA., Bethea, AS., Singleton, TE., Magalhaesm J,V., Garvin, D.F., Kochian, L.V. 2001. Physiological basis of reduced $\mathrm{Al}$ tolerance in ditelosomic lines of Chinese Spring wheat. Planta. $212,829-834$.

Pellet, D.M., Grunes, D.L., Kochian, L.V. 1996. Multiple aluminum-resistance mechanisms in wheat. Roles for root apical phosphate and malate exudation. Plant Physiol. 112, 591-597.

Raman, H., Zhang, K., Cakir, M., Appels, R., Garvin, D.F., Maron, L.G., Kochian, L.V., Moroni, J.S., Raman, R., Imtiaz, M., Drake Brockman, F., Waters, I., Martin, P., Sasaki, T., Yamamoto, Y., Matsumoto, H., Hebb, D.M., Delhaize, E., Ryan, P.R. 2005. Molecular characterization and mapping of ALMT1, the aluminium-tolerance gene of bread wheat (Triticum aestivum L.). Genome. $48,781-791$.

Rubio, R., Moraga, E., Borie, F. 1990. Acid phosphatase activity and vesicular-arbuscular mycorrhizal 
Seguel, A., Medina, J., Rubio, R., Cornejo, P., Borie, F. 2012. Effects of soil aluminum on early arbuscular mycorrhizal colonization of aluminum tolerant wheat and barley cultivars. Chil. J. Agric. Res. $72,449-455$.

Seguel, A., Cumming, J., Klugh-Stewart, K., Cornejo, P., Borie, P. 2013. The role of arbuscular mycorrhizas in decreasing aluminium phytotoxicity in acidic soils: a review. Mycorrhiza. 23, 167-183.

Seguel, A., Barea, J.M., Cornejo, P., Borie, F. 2015. Role of arbuscular mycorrhizal symbiosis in phosphorus-uptake efficiency and aluminium tolerance in barley growing in acid soils. Crop Pasture Sci. 66, 696-705.

Sieverding, E., 1991. Vesicular-arbuscular mycorrhiza management in tropical agrosystems. Deustche Gesellschaft Technische Zusammenarbeit (GTZ) GmbH, Eschborn.
Tabatabai, M.A., Bremner, J.M. 1969. Use of p -Nitrophenyl phosphate for assay of soil phosphatase activity. Soil Biol. Biochem. 1, 301-307.

Tang, Y., Garvin, D.F., Kochian, L.V., Sorrells, M.E., Carver, B.F. 2002. Physiological genetics of aluminum tolerance in the wheat cultivar Atlas 66. Crop Science. 42, 1541-1546.

Wright, S.F., Upadhyaya, A. 1998. A survey of soils for aggregate stability and glomalin, a glycoprotein produced by hyphae of arbuscular mycorrhizal fungi. Plant Soil. 198, 97-107.

Xiao, K., Bai, G.H., Carver, B.F. 2005. Nylon filter arrays reveal differential expression of expressed sequence tags in wheat roots under aluminum stress. J. Integr. Plant Biol. 47, 839-848.

Zagal, E., Sadzawka, A. 2007. Protocolo de métodos de análisis para suelos y lodos. Universidad de Concepción, Servicio Agrícola y Ganadero, Santiago, Chile. pp. 103. 